\title{
A Case Study on Performance Implications of Hybrid Strategy in Automotive Supplier Industry
}

\author{
Eren Durmus Ozdemir ${ }^{1}$, Saime Mecikoglu ${ }^{1}$ \\ ${ }^{1}$ Department of Business Administration, Faculty of Economics and Administrative Sciences, Akdeniz University, \\ Antalya, Turkey
}

Correspondence: Eren Durmus Ozdemir, Department of Business Administration Faculty of Economics and Administrative Sciences, Akdeniz University, 07058, Antalya, Turkey. Tel: +902423101839. E-mail: edurmus@akdeniz.edu.tr

Received: March 1, 2016

Accepted: March 18, $2016 \quad$ Online Published: March 25, 2016

doi:10.5539/ibr.v9n6p31

URL: http://dx.doi.org/10.5539/ibr.v9n6p31

\begin{abstract}
The aim of this study is to explore the impact of hybrid strategy on firm performance in a wire harness firm operating in the automotive supplier industry at Antalya Free Trade Zone in Turkey. It was the gap in literature concerning this relationship between hybrid strategy and firm performance under conditions of environment turbulence in the automotive supplier industry that motivated this study. The research question was pursued through in depth interviews with top-level managers of the firm. Data obtained from the interviews, observations and documents were analysed using NVivo software. The findings show that hybrid strategy influenced firm performance positively. Furthermore, the existence of environment turbulence positively influences hybrid strategy, whereas stable environment has a negative influence. Environment turbulence does not exert a direct influence on performance, but an indirect one, through hybrid strategy.
\end{abstract}

Keywords: automotive supplier industry, environment turbulence, firm performance, hybrid strategy

\section{Introduction}

This paper aims to investigate the impact of hybrid strategy on firm performance under conditions of environment turbulence in an automotive supplier firm at Antalya Free Trade Zone (FTZ) in Turkey. Hybrid strategy (also called mixed, integrated, or combination strategies) has attracted the attention of strategic management pioneers since the argument of Porter $(1980,1985,1996)$ that strategic purity or clear choice of one generic competitive strategy (i.e. low cost, differentiation, focus) contributed to better performance. According to Porter (1985), each of these three generic competitive strategies is a completely different way of creating a sustainable competitive advantage. Therefore, a firm must make a choice between low cost, differentiation or focus strategies or it will be stuck in the middle without a coherent strategy because each specific (pure) strategy involves a different set of resources and organizational arrangements. Although strategic purity initially received considerable support, (Dess \& Davis, 1984; Hawes \& Crittendon, 1984; Roos,Flinkman, Jäppinen, Lönner \& Warensjö, 2002; Lähtinen \& Toppinen, 2008), it was challenged in later studies (Campbell-Hunt, 2000; Parnell \& Hershey, 2005; Raynor, 2007; Salavou, 2010; Huang, 2011; Salavou, 2013; Shinkle, Kriauciunas \& Hundley, 2013). While some studies revealed that pure strategies improved performance (Ebben \& Johnson, 2005; Lechner, Gudmundsson \& Vidar, 2014; Hansen, Nybakk \& Panwar, 2015), others suggested that different generic strategies were linked to different aspects of performance (Chandler \& Hanks, 1994; Baum, Locke \& Smith, 2001). There is another group of studies, which indicated that hybrid strategies, combining elements of both generic competitive strategies, simultaneously lead to better performance (Carter, Stearns \& Reynolds, 1994; Kim \& Choi, 1994; Acquaah \& Yasai-Ardekani, 2008; Pertusa-Ortega, Molina-Azorín \& Claver-Cortés, 2009; Leitner \& Güldenberg, 2010; Hodgkinson, 2013; Parnell, 2013; Manev, Manolova, Harkins \& Gyoshev, 2014; Salavou, 2015). Hybrid strategies involving high level of emphasis on both cost-leadership and differentiation strategies simultaneously should be distinguished from stuck in the middle strategy where a firm fails to successfully pursue both cost-leadership and differentiation strategies (Acquaah \& Yasai-Ardekani, 2008). Nonetheless, between pure and stuck are hybrid strategies, regarded by some scholars to have potential (Carter, Stearns \& Reynolds, 1994; Kim \& Choi, 1994; Acquaah \& Yasai-Ardekani, 2008; Pertusa-Ortega et al., 2009; Leitner \& Güldenberg, 2010; Parnell, 2013).

At the centre of this debate, the concept of turbulent environment has been playing a key role as it could be considered the central part of hybrid strategy and firm performance. Claver-Cortés, Pertusa-Ortega and Molina-Azorín (2012) 
argue that it is not surprising to see that hybrid strategies have become a requisite objective for all firms in today's intense competitive environment that leads to turbulence. The modern era of globalization, high speed and instability have been at the origin of this need. In fact, many authors defend that business environments have been much more dynamic, unstable and competitive. These turbulent environments are commonly described by increased competitive intensity, disruptive changes in industry structure, volatility of demand, and unpredictability of customer behaviour; alongside instability of economic, social and political factors (Lapersonne et al., 2015). Turbulent environment also leads to unpredictable changes in competitor strategies. Especially in intensively turbulent environments, hybrid strategies are more effective, which create competitive advantage and enhance flexibility. The empirical study conducted by Shinkle et al. (2013) demonstrated that hybrid strategies were related to higher performance in turbulent environments. The strategic purity is probably too rigid and may not be suitable to compete under conditions increasing market and technological turbulence (Pertusa-Ortega et al., 2007).

There is still a small body of research in the literature addressing the issue of hybrid strategies and firm performance under conditions of market and technological turbulence in the automotive supplier industry (Proff, 2000, 2007). Therefore, the authors of this article focused on automotive supplier industry at Antalya FTZ, which is a turbulent environment and has achieved an assertive position with its production capacity, export volume and quality in the field of automotive supplier industry. The most important mirror wire harness, lighting wire harness, electronic transmission unit wire harness, gear shift wire harness, wiper wire harness, board computer wire harness factories are located at Antalya FTZ. In 2015, nearly every wire harness part of all automobile brands and models are manufactured in zone and exported particularly to the European Union, South American, North and South African, Middle East and Far East countries (www. asbas.com.tr, 2015). This case study is comprised of the first automotive wire harness supplier company at Antalya FTZ, which is one of the leading firms in the automotive wire harness supplier industry in Turkey. Moreover, this company has enjoyed a high total volume trade rate in recent years and provided considerable contributions to the economy of Antalya FTZ.

The paper is organized as follows: The first section summarizes the literature regarding hybrid strategy, firm performance, market turbulence, and technological turbulence. Next section deals with methodology and findings of case study. Lastly, the findings are discussed, limitations are presented and some recommendations are proposed for further research and other concerned practitioners.

\section{Literature Review}

\subsection{Discussion on Pure or Hybrid Strategy}

According to Porter (1980, 1985, 1996), competitive advantage involves the choice of clear positioning in the product-market space based on either low cost, differentiation or focus. He $(1980,1985)$ introduced that competitive advantage in long run is based on the firm's ability to achieve one of three basic types of generic strategy that stems from industry structure. Hence, he placed the dynamic relationship between generic strategy and industry structure at the center of his concept of competitive advantage. According to Porter (1985), each of these three generic competitive strategies is a completely different way of creating a sustainable competitive advantage. Therefore, a firm must make a choice between low cost, differentiation or focus strategies or it will be stuck in the middle without a coherent strategy since each pure strategy involves a different set of resources and organizational arrangements. He $(1985,17)$ described this situation, as "becoming stuck in the middle is often a manifestation of a firm's unwillingness to make choices about how to compete. It tries for competitive advantage through every means and achieves none, because achieving different types of competitive advantage usually requires inconsistent actions". Thus a firm can only achieve competitive advantage by adopting pure strategies, that is, by making a choice between low cost, differentiation and focus strategies; otherwise, combining generic strategies causes most businesses to be stuck in the middle and experience a poor performance (Porter, 1980, 1985).

Although issue of competitive strategies and their influence on performance has been examined for more than 30 years, recent researches are still interested in issue of whether firms can successfully pursue pure or hybrid strategies (Salavou, 2010). Hybrid strategy has been defined as a strategic approach that emphasizes both low cost and differentiation strategy (Pertusa-Ortega, Molina-Azorín \& Claver-Cortés, 2009; Claver-Cortés et al., 2012). In other words, hybrid strategy aims to provide much more monetary value to customers by combining low cost and high rates of differentiation (Thompson \& Strickland, 1999). The dimensional approach is essential to understand the concept of hybrid strategy (Pertusa-Ortega et al., 2009, 509-510). Miller and Dess (1993) defended the dimensional approach, which proposes that the generic competitive strategies should not be regarded as two unique strategies but as two dimensions according to which each firm must choose its position. They pointed out that Porter's framework could be improved by viewing it as providing two important dimensions rather than as two distinct strategies. Regarding the dimension approach, it can be said that success of hybrid strategies may depend on the number of dimensions on which 
emphasis is simultaneously placed. The complex and multidimensional strategies of a firm prevent it from imitating its strategic position and consequently, increasing its profitability. Furthermore, different studies related to the dimensional approach showed that competitive strategy was not only formed by two dimensions, but also established by various types of strategy (Pertusa-Ortega et al., 2009, 512). For instance, the present study follows Mintzberg's (1988) dimensions and considers four types of differentiation strategies while also applying the strategic orientations proposed by Olson, Slater and Hult (2005) which were briefly defined below:

Differentiation by quality offers a superior quality based on reliability, durability and performance. Differentiation by image refers to creating a distinctive image for a product using marketing. Differentiation by design requires offering products with unique features and design configurations. Differentiation by support implies providing a distinctive service during the sale or after the sale of the product.

Innovation orientation means that the firm is not only open to but also seek out new ideas in both its technical and administrative domains (Han, Kim \& Srivastava, 1998; Hurley \& Hult, 1998; Lilien, Morrison, Searls, Sonnack \& von Hippel, 2002). It encourages risk taking and enhances the likelihood of developing radically new products. Customer orientation means that the firm tries to gain competitive advantage by placing the highest priority on the creation and maintenance of the customer value. Olson et al. (2005) noted that the differentiation advantage would be derived from the customer, competitor or innovation-oriented behaviours. The cost advantage means that a firm sells a standard product and/or service at a lower price than average price, but it also could mean that the firm prices its products below the market average price while still enjoying greater profit margins by having superior internal efficiencies and lower operating costs.

In the contemporary intensely competitive environment, it is not surprising to see that hybrid strategies have become a requisite objective for all firms (Claver-Cortés et al. 2012). The arguments on this subject are still under review because of the researchers' inconsistent empirical findings. For example, in the study of Brege, Nord, Sjöström and Stehn (2010) it was found that differentiation had positive impacts on performance than low cost, which was consistent with the findings of previous studies conducted by Wright, Kroll, Tu and Helms (1991), Roos et al. (2001, 2002), Ebben and Johnson (2005), Lähtinen and Toppinen (2008), and Lechner et al. (2014), all of whom pointed to the importance of strategic purity. Thornhill and White $(2007,553)$ found that pure strategies never did less well and often did better than hybrid strategies. However, another empirical study by Pertusa-Ortega et al. $(2009,520)$ demonstrated that low cost and differentiation strategies can be developed in a complimentary way. Spanos, Zaralis and Lioukas (2004) support the superiority of hybrid strategy over the pure forms for competitive advantage in Greek firms. Similarly, empirical study by Salavou (2010) showed that hybridists (service firms placing high emphasis on low cost and differentiation) are better performers compared with non-strategists (strategy-less firms) and confused strategists (service firms placing medium emphasis on differentiation). According to the findings of these authors, implementation of hybrid strategies is capability of a firm, which is a resource that leads to better performance. Otherwise, the pure strategy may result in a wide variety of problems related to the firm's performance. For example, Miller (1992) argued that the pure strategies might cause inflexibility and narrow an organization's vision. Implementing a hybrid strategy is bound to require an organizational structure, which combines flexibility and adaptability. In this context, Leitner and Güldenberg (2010) stated that hybrid strategy allowed firms to maintain a greater agility and flexibility in offering products that focus both on costs and on specific product features. In the pure strategies, however, competitors may be able to imitate strategies, resources or organization structure more easily than hybrid strategies and this might lead to another problem in the pure strategy (Claver-Cortes et al., 2012, 995). Beal and Yasai-Ardekani (2000), consistently with Claver-Cortes et al. (2012), proposed that hybrid strategies may yield multiple sources of advantage over rival firms, and so allow achievement of higher performance and this makes it difficult to imitate hybrid strategies. In conclusion, the firms' ability to use hybrid strategy may be more important than maintaining competitive advantage (Carter, Stearns \& Reynolds, 1994; Kim \& Choi, 1994; Parnell \& Hershey, 2005; Pertusa-Ortega et al., 2007; Acquaah \& Yasai-Ardekani 2008; Pertusa-Ortega, Molina-Azorín \& Claver-Cortés, 2009; Leitner \& Güldenberg, 2010; Hodgkinson, 2013; Parnell, 2013; Manev, Manolova, Harkins \& Gyoshev, 2014; Salavou, 2015).

\subsection{Impact of Environmental Turbulence on Choice of Strategy}

In the last decades, the emergence of new technologies, new players in the world markets and managerial know-how lead to a turbulent environment due to dynamics of globalization. Turbulent environment is commonly described by increased competitive intensity, disruptive changes in the industry structure, volatility of demand, and unpredictability of customer behaviour; alongside instability of economic, social and political factors (Lapersonne et al., 2015). Many authors defend that these factors may help firms to achieve competitive advantages because turbulent environments may increase ambiguity (Lippman \& Rumelt, 1982; Eisenhardt \& Martin, 2000; Noda \& Collis, 2001); therefore, the firms' ability to imitate resources or strategies decreases. Previous studies (Miles \& Snow, 1978; Dent, 1990) pointed out that organizations within turbulent environments have different strategic choices. Hence, these organizations might require 
different resources to enhance their organizational performance. Miller $(1988,1991)$ stated that the low cost strategy would be more advantageous in stable environments rather than unstable environments, whereas strategies that differentiate offerings via effective marketing or innovation would thrive in uncertainty. In other words, the matching of strategy and environment is essential to enhance the organizational performance.

In turbulent environments, such as marketing and technology, where products and services change at short intervals, the static resources alone cannot help sustain the firm performance (Galunic \& Rodan, 1998). D'Aveni (1994) pointed out that market and technological turbulences contain unpredictable changes in competitor strategies. Firms developing timely responsiveness, rapid and flexible product innovation, and strategies to compete successfully are important in market and technological turbulence (Teece et al., 1997); hence, in these environments, there is a need for developing different strategies that can change the technological and managerial aspects. A firm's competition potential is related to its internal capabilities and resources, and its ability to effectively formulate, implement and evaluate different strategies. A turbulent environment requires that firms not only manage their current resources effectively, but also be flexible to change their strategies (Pettus, Kor \& Mahoney, 2009). Especially, in intensively turbulent environments, hybrid strategies are more effective, which create competitive advantage and enhance flexibility (Shinkle, Kriauciunas \& Hundley, 2013). Hybrid strategy is regarded as one of the most important sources of sustainable competitive advantage in an increasingly turbulent environment; hence, it leads to product and process improvements, and ensures continuous advancements. Therefore, this helps firms to survive, to grow more quickly, to be more efficient and flexible and to be more profitable compared to the pure strategy (Shinkle, Kriauciunas \& Hundley, 2013). D'Aveni et al. (2010) pointed out that in a turbulent environment marked by high level of competition, instability of demand and fast transformation of the industry, the rules of strategic purity lose their importance because at best they have a temporary validity.

According to the findings of many empirical studies, hybrid strategy enabled higher performance in turbulent environments (Leitner \& Güldenberg, 2010; Claver-Cortés et al., 2012; Shinkle et al., 2013), however researches are still limited in different sectors especially the automotive supplier industry (Proff, 2000; 2007). Only one recent study, in a case study of the German automotive industry, Proff (2000) identified six turbulent environmental factors that have been influencing the automotive industry and lead to the adoption of a hybrid approach. On the demand side, a stagnating demand for new cars, an increasing practice of providing the full range of equipment as standard rather than as optional, reducing profit, and the increasing demand for niche product, and increasing complexity and cost. On the supply side, an increase of differentiation of product lines with more variety of models, an overcapacity and a decentralization of production have brought an increase of complexity. With a view to contributing to the gap in the literature, the aim of present paper is to the impact of hybrid strategy on firm performance under conditions of market turbulence and technological turbulence of an automotive wire harness firm operating at Antalya FTZ in Turkey.

\section{Methodology}

\subsection{Data Collection Method}

Data of study, collected through in depth interviews and document analysis were analysed to draw some conclusions concerning the impact of strategy on the wire harness supplier company operating in the automotive supplier industry at Antalya Free Trade Zone. In a 2-month period, semi structured interviews were held with the Board of Directors, Quality Manager, Management Information System Manager, Human Resources Manager, Sales Manager, Purchasing Manager, Finance Manager, Product Manager of the firm, all whom have active roles in the strategic management processes. Each interview gave an idea about the next interview to be held and eventually 16 interviews were completed during the study. The authors held the interviews using semi-structured interview questions, which were asked face-to-face, tape recorded upon consent, and transcribed after the interview session. Each interview took 90 to 120 minutes. The transcription texts and the selected documents were subjected to content analysis, first highlighting the important and pertinent information and then picking up the main themes, central ideas or important details. The data obtained from the interviews, observations and documents were analysed using the Nonnumerical Unstructured Data: Indexing, Searching and Theorizing (NUD*IST Vivo or NVivo) software program (Fraser, 1999). The original expressions of the interviewed managers were conserved. The official annual reports of the Association of Automotive Parts and Components Manufacturers (TAYSAD), Automotive Manufacturers Association (OSD), news reports, interviews and articles published in some popular magazines and newspapers, some news articles found on the internet, publications about the Free Trade Zones in Turkey formed the database for document analysis as a supplement to the below mentioned data collection.

\subsection{In-depth Interview Questions}

The semi-structured interview questions were the basic data collection tools of the study. These tools were based on the previous studies and publications about automotive wire harness supplier sector. The semi-structured interview question form consisted of three parts. First part contained some relevant information about the departments of the firm and 
second part contained strategic orientations, differentiation dimensions and technological and market turbulence. Interview questions were adapted to the sector from the study by Olson et al. (2005),Minztberg (1988), Robinson and Pearce (1988)and Dess and Davis (1984).The third part was dedicated to understand the satisfaction of the firm with its performance and interview questions were adapted to the sector from the study by Venkatraman (1989). In this study, subjective measures of performance were evaluated due to the difficulty of gathering hard financial data from private companies (Venkatraman, 1989).

\section{Findings}

\subsection{Automotive Supplier Industry in Turkey}

The automotive industry in Turkey is one of the most important industries for national economy due to the fact that it provides added value and creates employment (Wasti, Kozan \& Kuman, 2006). This industry also contributes to the improvement of the competitive power of the country by investing and innovating continuously (Cleff, Grimpe \& Rammer, 2015), creating technical jobs, and spreading the technical culture to the other relevant industries and to the society in general. In parallel to the development of the automotive industry, the supplier industry has also developed in Turkey in 1990's. Until 2000 when investments were made in order to produce a new economic model in the country (e.g. The Customs Union that was established with European Union accelerated this process), the industry became a competitive sector. In 2000's, Turkish automotive firms' efforts for quality approach developed the automotive supplier industry, and supplier industry utilized many programs, such as quality standards (ISO 9000, QS 9000), and processing management (Samsunlu, 2007, 44). Thus automotive supplier industry started to sell products to the main automotive industry, not only in Turkey, but also around the world.

Turkish automotive part suppliers play a key role in the global automotive sector with their exports. Turkey was the Europe's $5^{\text {th }}$ and the world's $16^{\text {th }}$ largest automotive producer with a total vehicle production over 1 million in 2013 (www.bcct.org.tr, 2015). Turkey's annual motor vehicle products have been exported by $60 \%$ to $80 \%$ since 2000 (www.osd.org.tr, 2015). Turkish suppliers export to more than 150 countries, including USA and major Latin American countries. In 2012, there were 47 registered automotive suppliers in Turkey with revenues exceeding $\$ 40$ million (www.inves.gov.tr, 2015). The sector report entitled "The Journey of Turkish Automotive Sector into the Future" showed that developing domestic market and increasing capabilities of the Turkish automotive parts manufacturers presented a high growth potential for the domestic parts manufacturers (www.osd.org.tr, 2015). On the other hand, the automotive supplier sector has been supported through the regulations of the government in recent years. The automotive supplier industry is the leading manufacturing sector in Turkey, because the regulations of the government incentivize this sector with grants. For example, the addendum numbered 2012/3305 regarding the new incentive system that came into force along with the "Decision on Government Supports for Investments" upon the Council Of Ministers' Decree has introduced a lot of changes in and opportunities for the automotive industry investments. With the relevant regulation, investors were allowed to import their products from A, B and C-segments without paying duty customs. With the last favourable changes introduced to the automotive supplier sector in the incentive package upon the Council of Ministers' Decision No.2013/4288 published in the Official Gazette of February 15, important amendments were made in the new incentive system to the favour of the automotive sector. Automotive investments to be made in the "motor land vehicles main industry" have been included in the "priority investments" with the relevant decision (www. taysad.org.tr, 2015). Finally, the Turkish automotive supplier industry is estimated to be one of the fastest growing sectors in the near future.

\subsection{Profile of the Firm}

The field study of present case was carried out in Antalya FTZ in Turkey. Although automotive supplier industry is clustered in certain cities of Turkey, such as Bursa, Kocaeli, İstanbul and Konya; Antalya FTZ automotive supplier industry has been increasingly attracting attention in the last years. Therefore, this study is focused on the automotive supplier industry at Antalya FTZ that is a turbulent environment, which has achieved an assertive position with its production capacity, gained a share in the international market and export volume in the automotive supplier industry. The most important mirror wire harness, lighting wire harness, electronic transmission unit wire harness, seat adjustment wire harness, gear shift wire harness, signal lever harness, board computer wire harness are produced by these factories that are located at Antalya FTZ. In 2015, almost every wire harness part of all automotive brands and models have been manufactured in this zone and exported particularly to the European Union, South American, North and South African, Middle East and Far East countries (www. asbas.com.tr, 2015).

The firm in this case study is the first automotive wire harness supplier company (W company) ${ }^{(\text {Note } 1)}$ at Antalya FTZ, while it is also one of the leading firms in the automotive wire harness supplier industry that has been experiencing a rapid and dynamic growth in Turkey. This firm has enjoyed a high total volume trade rate in recent years and provided considerable contributions to the economy of Antalya FTZ. Thus, in this present study, it seemed worthwhile to investigate the conceptual relations of W company at Antalya FTZ in Turkey. Therefore, the paper will address the 
following questions: "To what extent does the automotive wire harness firm pursue strategic purity, and to what extent does it follow hybrid strategy?", "what are the implications of hybrid strategy on firm performance in the automotive supplier industry?", "what is the extent of market and technological turbulence in the automotive supplier industry?".

\subsection{Findings on the Extent of Hybrid Strategy Pursued by the Firm}

The question primarily examined in this study was whether the automotive wire harness firm followed strategic purity or hybrid strategy. A specific question was dedicated to the respondents' perception on purity or hybrid operations in strategic management process in the automotive supplier industry. Furthermore, the respondents commented on the same topic during the interview while answering this question. In this study, strategic orientations (Olson et al., 2005) and differentiation dimensions (Mintzberg, 1988) were used to understand hybrid strategies.

One of the most important results derived from the interviews was that frequently mentioned innovation operations were related with the high firm performance. The Quality Manager of the W company stated, "We are not afraid of change and innovation. Every moment, we try something new, we change, and we try to apply innovative activities through continuous improvement. In our firm continuous improvement has been the motto of lean manufacturing since 2007 '. Especially in automotive supplier industry, lean manufacturing system is considered as an organizational process that is able to strike an effective balance between the element of standardization and the innovative forces represented by innovation and kaizen (Neagoe \& Klein, 2009; Charles \& Chucks, 2012). Kaizen is one of the most prominent principles of lean manufacturing, which means conceptualization of continuous improvement in the standard way of working through submission of creative and problem solving ideas by the employees (Miller, 2003). According to Womack, Jones and Roos (2007), “.......kaizen is a Japanese term for a suggestion system in which employees are motivated to come up with small ideas and implement the ideas themselves rather than presenting ideas for someone else to analyse and execute". When applied to the workplace, kaizen refers to activities that continuously improve all functions and involve all employees. The high frequency of comments made by all respondents on innovation operations underlined the inclusion of employee suggestion systems as part of the lean manufacturing system. The General Manager/Founder stated “...our company encourages our personnel to take active role in kaizen. We use a suggestion system to support the continuous improvement. It's very important for us. For example, we are offering monetary reward for innovative ideas at all levels of the organization. As a result of this system, the number of applicable suggestions has increased sharply, compared to the previous years. Our suggestion system is a functional strategy for innovation, creativity and sustainability in the market”. Quality manager narrated, “....when workers propose a project or solution, it is discussed for implementation in manufacturing. Furthermore, the worker who proposed the idea will be responsible for the implementation and development of the project". Purchasing manager of the W company expressed as "for maintaining our continuous improvement; we participate in international fairs to follow the technological and sectorial developments continuously. We must participate in these fairs and we must purchase new machinery and equipment because the automotive supplier industry is very dynamic. Therefore, we are very satisfied with our technologic equipment and IT systems". This is an indication of the kaizen and lean management, which enabled the firm to significantly improve its innovation activities (or orientation) and firm performance.

The interview with the managers of $\mathrm{W}$ company also indicated that the firm continuously tries to discover the needs and expectations of current and potential customers. Almost all the managers interviewed confirmed that W company could be called a customer-oriented firm. Sales manager pointed out as "it is right: we are not working in the services sector. But we are working in the automotive industry. It means that we have to produce a variety of products characterized by numerous features, options, sizes, and colours according to customers' needs. Effective collaborations with the customer are the key competitive priority for us in our operations. For example, we organize customer satisfaction meetings in our firm every week. In these meetings, all departments mutually discuss their customer relationship management performance. Our principle is 'the customer is equal to firm performance'”. Quality manager also emphasized, "We always focus on customer satisfaction. For example, we monitor the customer satisfaction through account representatives using regular customer satisfaction surveys and customer assessment forms. But the most important point is, we receive on-site customer inspections about the production, quality and costs to see whether they comply with the standards in the contracts". This result demonstrated a clear relationship between customer orientation and W company performance. Complementary comments were made indicating that the respondents were very satisfied with the after sales services and customer satisfaction.

As mentioned above, hybrid strategy combinations of manufacturing firms and their performance found to be related (Spanos et al., 2004; Pertusa-Ortega et al., 2009; Leitner \& Güldenberg, 2010; Parnell, 2013). Empirical studies documented that low cost strategy, which is one of hybrid strategies, increases performance. In low cost oriented firms, the highest priority is achieving operational efficiency. Managers continuously pursue better ways of reducing costs, which is a low cost position, by emphasizing "aggressive construction of efficient-scale facilities, vigorous pursuit of cost reductions from experience, tight cost and overhead control, avoidance of marginal customer accounts, and cost 
minimization in areas like research and development, services, sales force, advertising, etc. (Porter, 1980)". During the interviews respondents frequently stressed the fact that low cost operations in automotive supplier industry were required for competitiveness and survival. The General Manager/Founder also mentioned about low cost operations and said "Our Company came to the zone in 1992. Thus, W company is one of the leading firms in automotive wire harness supplier industry in Antalya FTZ. I am the owner and founder of this firm. When I decided to invest in automotive supplier industry, I looked for a location for the factory. The convenient location of Antalya FTZ combined with the low cost land, unused machine park hangars in the Zone and convenient FTZ policies, geographical advantage of the FTZ and proximity of Antalya Harbour for wire harness production were the major incentives for me. All these factors indicated that we would have the ability to operate with low cost. Since then, we have focused on cost control as a part of our operation strategy. Moreover, with the competitiveness and pressures from the technological improvements in the automotive wire harness industry, cost control has become a necessity to survive in the global market. The pressure is mostly coming from Eastern European countries, China and India with wage-cost advantages. In relation to this fact, economies of scope and scale gain more importance." This conclusion explains why $\mathrm{W}$ company is operating in Antalya FTZ, which offers low cost operations given its proximity to Antalya harbour and tax exemption.

In the case of $W$ company, low cost operations could be ensured through continuous process engineering and monitoring of processes without affecting the product quality. Purchasing Manager underlined this, as "For 5 years, we have been satisfied with the profit margins. Although the cost pressure from the market and customers widely depend on the supply costs of materials and parts, our products must be produced according to the quality standards e.g. ISO 9001. For example, in my department, our activities must balance the quality and cost control. This is a strategic art and this is what we do". As another example of low cost operations, Finance Manager expressed "Our customers are very impressed with the cost and price offers. Therefore, our firm is able to offer considerable price advantages to our customers by minimizing costs, and we are thankful to the government and Free Zone Directorate and The Zone Operating Company (ASBAS) for their incentives. For example, in W company, Solar Photovoltaic Cable Sets Production is supported by West Mediterranean Development Agency and Republic of Turkey, Ministry of Development. Thus, we have reduced our transaction costs in new products while increasing our performance". Most of the managers seem to have been persuaded by the promises of the Law No.2013/4288 regarding the benefits of process innovation and cost control, they have also seen its consequences in relation to firm performance. The overall results indicated that the innovation orientation, competitor orientation and cost orientation for high-level firm performance were perceived as sources of competition in the automotive supplier industry.

\subsection{Findings on the Performance Implications of Hybrid Strategy}

As mentioned above, there are situations in which one cannot achieve a single low cost position in a given industry; hence there is a need for differentiation in order to maintain a sustainable competitive advantage. In other words, using hybrid competitive strategies may help obtaining several sources of advantage, and thus make it possible to achieve higher performance levels. All the hints obtained from the interview transcriptions indicated that all firms in the automotive supplier industry have to combine cost and differentiation strategies in a balanced way for a sustainable competitive advantage. Almost all managers interviewed confirmed that their firm increasingly adopted elaborate strategic types. It was inferred from this result that hybrid strategies appear to be the prevailing and best-performing strategic pattern for automotive supplier industry in Turkey. The data compiled from these interviews indicated that quality and support operations were considered as major differentiation strategies for high-level performance in the automotive wire harness sector. As explained above, innovation operations found related to the high firm performance of the $\mathrm{W}$ company, also in line with lean management. It is well known that automotive wire harness market demands specialized technology, innovation and quality material. Therefore, it was quite foreseeable to find out that innovation orientation and differentiation by quality were relevant for the firm in this case study. Product manager of the $\mathrm{W}$ company pointed out "I want to explain our journey to lean management. $\mathrm{W}$ company has been implementing lean manufacturing system since 2007. As of today, more than $90 \%$ of the production lines have been converted to the lean production system. Lean production, originally derived from "Toyota Production System", can be described as eliminating every step, every action and every practice, every cost that does not create a value added. So, the focus is on modelling processes to be more efficient with especially improving the quality. In our company, there are certainly 3 business operations in which it may be possible to improve all positions, namely quality management, innovation management and cost management. It implies higher quality (and thus differentiation), lower costs and increased productivity, which in turn may give our firm a greater market share and better competitive position".

Quality manager also mentioned differentiation by quality and said, "Right after the foundation, $W$ company initially prioritized establishing a sustainable quality system. According to W company's' management team, a sustainable quality system consists of a set of fixed manufacturing procedures and rules aiming to ensure that a product meets a predetermined and widely acknowledged set of standards. We knew that, quality assurance was the manufacturing 
process designed to manage and update the quality system, which is constantly able to guarantee and demonstrate that the system conforms to the agreed set of specific standards. In our sector, if you want to increase your performance you have to adopt 'Quality Assurance Standards'. Consequently, W company received the ISO 9002 certificate from DQS Germany shortly after the start of the production in June 1995. In June 2000 we received QS-9000 certification from DQS Germany. Our firm obtained ISO/TS 16949:2002 certificate in 2003 and ISO 14001 in 2009. We finally obtained ISO/TS 16949:2009, ISO 9001:2008 and EN ISO 14001:2004. These are very important for high performance". It was not surprising to find that ISO/TS 16949:2009, in conjunction with ISO 9001:2008, defines the quality management system requirements for the design and development, production and when relevant, installation and service of automotive-related products (www.iso.org 2015).

Another question asked to respondents by the researchers focused on their perception concerning the differentiation by support strategy. The number of respondents who perceived this strategy is in accordance with the quality strategy. The Sales Manager indicated " $W$ company's mission clearly reads as 'to increase the market share by manufacturing under the economic conditions in accordance with the quality assurance policies, including also the after sale of the product'. Our job is not finished when we sell our product to customers. Actually, our own work is just getting started. Our job covers both selling the product and after sales. Why is after sales becoming so important in our firm? It's because our customers are special".

The overall results indicate that only two differentiation strategies were relevant for high performance in W company: quality differentiation and support differentiation as described above. They showed no indication of image differentiation and design differentiation.

\subsection{Findings on the Environmental Turbulence of the Industry}

The third examined question in this study was whether the environment turbulence impacts the relationship between hybrid strategy and firm performance in automotive supplier industry. The high frequency of comments made by all respondents on environment turbulence indicates that marketing environment and technological environment as part of the competitive environment in automotive supplier industry. According to General Manager/Founder, "W company's main competitors are in international markets; because of W Company sells small amounts of goods to the domestic automotive producers within country. If you operate in automotive supplier industry, you have to focus more markets in order to achieve high performance. Most importantly, W Company operates at Antalya FTZ. This means W Company is facing a period of constant change: enforced legislation, customer demand, technological revolution, and new competitors. W company must adapt to FTZ policies and the foreign trade regulations of the government". Information system manager pointed out that, "globally, the automotive supplier sector is going through a big change: On the one hand, critical technical innovations are made such as electric vehicle, minimization of carbon dioxide emission, lesser fuel consumption and self-driving cars etc. on the other hand, there is a noteworthy change in the global competition. In recent years, technological environment is dynamic. Therefore, $W$ Company invests for new innovation activities (like information technologies or process innovation), which are our mission. W Company has flexible organization structure for different strategies in changing environment". During the interviews the respondents frequently stressed on the fact that marketing environment and technological environment in the automotive supplier industry influenced the firm performance through hybrid strategies. Especially product manager also mentioned about environment turbulence and said, "Automotive supplier industry becomes more global, automakers are striving to use flexible, to adapt to changing customer preferences and free up resources to invest in innovation, to satisfy increasingly tough environmental regulations. We (W Company) have to use different strategies simultaneously." As mentioned above, in turbulent environments such as marketing and technology, the auto supplier firms have to be flexible to change their strategies and resources. Complementing comments were made indicating that the respondents were very satisfied by increase in sales, profit margin, total sales income, technological equipment and overall performance of the firm.

\section{Conclusion}

An important question explored in this study was hybrid strategies are the most effective for automotive supplier firms in their pursuit of superior performance in a turbulent environment. The question was explored based on the case of Antalya FTZ in Turkey, which demonstrated that this zone was a highly regulated environment that achieved an assertive position in its production capacity, gained share from the international market and export volume in the automotive supplier industry. This was deduced from the first automotive wire harness supplier company (W company) at Antalya FTZ which is also one of the leading firms in the automotive wire harness supplier industry that has been experiencing a rapid and dynamic growth in Turkey. The research questions were pursued through observations, document analysis and in depth interviews with the top-level managers of the firm all of whom have active roles in the strategic management processes. The results of this study indicate that hybrid strategy that includes detailed innovation orientation, customer orientation, cost orientation, quality differentiation, and support differentiation strategies of the 
automotive wire harness firm was found to be associated with the performance. It was concluded that the firm in the automotive supplier industry, at least in this study, combined the cost and differentiation strategies in a balanced way for a sustainable competitive advantage. This may be due to the fact that the biggest and most powerful players in the automotive industry are still the large assemblers that design and assemble the majority of their vehicles and hold the strongest brand equity with consumers, which allows them to pursue image differentiation and design differentiation.

Another contribution of this paper to the literature may be attributed to the fact that it is one of the first studies to deal with the relationship between hybrid strategy and firm performance in the context of market turbulence and technological turbulence in the automotive supplier industry at a FTZ. The automotive supplier industry and FTZ are highly regulated by the national states and international institutions. Therefore, the performance of a firm depends not only on its own hybrid strategy but also on the resources provided by the organizational environment. Thus, the FTZ policies, foreign trade regulations of the government as well as the other regulations of the government incentivizing this sector can be jointly responsible for the high or low competitiveness of a certain sector in the country. This finding is consistent with the assertion of Proff (2000) stating that the changes in the automotive supplier industry, particularly in the supply and demand conditions, require the availability of hybrid strategies and resources at the same time. According to this author, on the supply side, forecasts are becoming increasingly difficult because product cycles are becoming shorter and discontinuities are increasing. On the demand side, customer requirements are converging; lifestyles are becoming more diverse and needs are more individual. Therefore, it was not surprising to find that the overall performance of the automotive supplier firm was related to its dynamic capabilities like managerial capabilities to effectively formulate, implement and evaluate different strategies (Mahoney, 1995; Adner \& Helfat, 2003), strategic flexibility to change their current resources effectively (Sanchez, 1995) and innovation operations (Cleff et al., 2015) to respond to supply and demand conditions (Rothaermel \& Hess, 2007) in a dynamic environment.

In conclusion, even though this study was a case study, it provides some clues that strategic purity in the automotive supplier industry is probably too rigid and may not be suitable to compete in an environment with increasing market and technological turbulent. The reason why hybrid strategies are relevant to firm performance in a dynamic environment may be explained with the characteristics of industry. The automotive supplier industry is a capital intensive industry based on mass production. Hence, firms tend to focus on new product innovations and changes in product lines. This requires a particular engagement in dynamic capabilities in order to improve performance. Therefore, the impact of hybrid strategy on firm performance under conditions of market turbulence and technological turbulence in the automotive supplier industry should be studied in reference to such concepts as competitive intensity, organizational structure and dynamic capabilities in further studies.

The limitation of this study concerns its generalizability due to the fact that automotive supplier firms are few in number and can only be studied in the form of case studies. The findings will only provide some clues to develop propositions regarding the impact of hybrid strategy on firm performance in relevant environment turbulence contexts. Future studies should access a reliable sample of automotive supplier firms or another sector in similar contexts to be able to draw some theoretical conclusions.

\section{References}

Acquaah, M., \& Yasai-Ardekani, M. (2008). Does the implementation of a combination competitive strategy yield incremental performance benefits? A new perspective from a transition economy in Sub-Saharan Africa.Journal of Business Research, 61, 346-354. http://dx.doi.org/10.1016/j.jbusres.2007.06.021

Adner, R., \& Helfat, C. (2003). Corporate effects and dynamic managerial capabilities. Strategic Management Journal, 24, 1011-1025. http://dx.doi.org/10.1002/smj.331

Akan, O., Allen, R. S., Helms, M. M., \& Spralls III, S. A. (2006). Critical tactics for implementing Porter's generic strategies. Journal of Business Strategy, 27(1), 43-53. http://dx.doi.org/10.1108/02756660610640173

Ambe, I. M., \& Badenhorst-Weiss, J. A. (2010). Strategic supply chain framework for the automotive industry. African Journal of Business Management, 4(10), 2110-2120.

Antalya Free Trade Zone Inc.- ASBAS. Retrieved August 15, 2015 from http//www. asbas.com.tr

Association of Automotive Parts \& Component Manufacturers. TAYSAD Sektör Raporu. (2015). Retrieved November 13, 2015 from http//www. taysad.org.tr

Automotive Manufacturers Association-OSD. Retrieved July 15, 2015 from http//www.osd. org.tr

Baroto, M. B., Abdullah, M. M. B., \& Wan, H. L. (2012). Hybrid strategy: A new strategy for competitive advantage. International Journal of Business and Management, 7(20), 120-133. http://dx.doi.org/10.5339/ijbm.v7n20p120

Baum, J. R., Locke, E. A., \& Smith, K. G. (2001). A multidimensional model of venture growth. The Academy of 
Management Journal, 44(2), 292-303. http://dx.doi.org/10.2307/3069456

Beal, R. M., \& Yasai-Ardekani, M. (2000). Performance implications of aligning CEO functional experiences with competitive strategies. Journal of Management, 26(4), 733-762. http://dx.doi.org/10.1177/014920630002600407

Bodlaj, M., \& Rojsek, I. (2010). The market orientation of Slovenian companies: Two-group comparisons. Economic and Business Review, 12(2), 89-108.

Brege, S., Nord, T., Sjöström, R., \& Stehn, L. (2010). Value-added strategies and forward integration in the Swedish sawmill industry: Positioning and profitability in the high-volume segment. Scandinavian Journal of Forest Research, 25(5), 482-493. http://dx.doi.org/10.1080/02827581.2010.496738

British Chamber of Commerce Turkey 1887. Retrieved October 13, 2015, from http//www. bcct.org.tr

Calingo, L. M. R. (1989). Achieving excellence in strategic planning systems. Advanced Management Journal, 54(2), 21.

Campbell-Hunt, C. (2000). What have we learned about generic competitive strategy? A meta analysis. Strategic Management Journal, 2, 127-154. http://dx.doi.org/10.1002/(SICI)1097-0266(200002)21:2<127::AID-SMJ75>3.0.CO;2-1

Carter, N. M., Stearns, T. M., \& Reynolds, P. D. (1994). New venture strategies: Theory development with an empirical base. Strategic Management Journal, 15(1), 21-41. http://dx.doi.org/10.1002/smj.4250150103

Chandler, G. N., \& Hanks, S. H. (1994). Market attractiveness, resource-based capabilities, venture strategies, and venture performance. Journal of Business Venturing, 9(4), 331-349.

http://dx.doi.org/10.1016/0883-9026(94)90011-6

Charles, A. A., \& Chucks, O. K. (2012). Adopting the kaizen suggestion system in South African lean automotive components companies. Science Journal of Business Management, ISSN:2276-6316. http://dx.doi.org/10.7237/sjbm/266

Claver-Cortés, E., Pertusa-Ortega, E. M., \& Molina-Azorín, J. F. (2012). Characteristics of organizational structure relating to hybrid competitive strategy: Implications for performance. Journal of Business Research, 65, 993-1002. http://dx.doi.org/10.1016/j.jbusres.2011.04.012

Cleff, T., Grimpe, C., \& Rammer, C. (2015). Identifying lead markets in the European automotive industry: An indicator-based approach. Industry and Innovation, 22(6), 496-522. http://dx.doi.org/10.1080/13662716.2015.1080047

D'Aveni, R. A. (1994). Hypercompetition: Managing the dynamics of strategic maneuvering. New York: The Free Press.

D'aveni, R. A., Dagnino, G. B. \& Smith, K. G. (2010). The age of temporary advantage. Strategic Management Journal, 31, 1371-1385. http://dx.doi.org/10.1002/smj.897

Davis, P. S., Dibrell, C. C., \& Janz, B. D. (2002). The impact of time on the strategy- performance relationship: implications for managers. Industrial Marketing and Management Journal, 31(4), 339-347. http://dx.doi.org/10.1016/S0019-8501(01)00168-7

Day, G. S. (1989). Deciding how to compete. Planning Review, September/October, 18-23. http://dx.doi.org/10.1108/eb054269

Dent, J. F. (1990). Strategy, organization and control: Some possibilities for accounting research. Accounting, Organizations and Society, 15(1), 3-25. http://dx.doi.org/10.1016/0361-3682(90)90010-R

Deshpandé, R., Farley, J. U., \& Webster Jr., F. E. (1993). Corporate culture, customer orientation, and innovativeness in Japanese firms: A quadrad analysis. The Journal of Marketing, 57(1), 23-37. http://dx.doi.org/10.2307/1252055

Dess, G. G., \& Davis, P. S. (1984). Porter's (1980) generic strategies as determinants of strategic group membership and organizational performance. Academy of Management Journal, 27(3), 467-488. http://dx.doi.org/10.2307/256040

Dess, G. G., Lumpkin, G. T., \& McGee, J. E. (1999). Linking corporate entrepreneurship to strategy, structure, and process: Suggested research directions. Entrepreneurship Theory and Practice, 23, 85-102.

Ebben, J. J., \& Johnson, A. C. (2005). Efficiency, flexibility, or both? Evidence linking strategy to performance in small firms. Strategic Management Journal, 26(13), 1249-1259. http://dx.doi.org/10.1002/smj.503

Eisenhardt, K. M., \& Martin, J. A. (2000). Dynamic capabilities: What are they? Strategic Management Journal, 21 10/11, 1105-1121. http://dx.doi.org/10.1002/1097-0266(200010/11)21:10/11<1105::AID-SMJ133>3.0.CO;2-E

Fraser, D. (1999). QSR NUD*IST Vivo: Reference Guide. Melbourne: Qualitative Solutions and Research Pty. 
Galunic, D., \& Rodan, S. (1998). Resource re-combinations in the firm: Knowledge structures and the potential for Schumpeterian innovation. Strategic Management Journal, 19(12), 1193-1201.http://dx.doi.org/10.1002/(SICI)1097-0266(998120)19:12<1193::AID-SMJ5>3.0.CO;2-F

Hambrick, D. C. (1983). Some tests of the effectiveness and functional attributes of Miles and Snow's strategic types. Academy of Management Journal, 26(1), 5-26. http://dx.doi.org/10.2307/256/32

Han, J. K., Kim, N., \& Srivastava, R. K. (1998). Market orientation and organizational performance: Is innovation a missing link? The Journal of Marketing, 62(4), 30-45. http://dx.doi.org/10.2307/1252285

Hansen, E., Nybakk, E., \& Panwar, R. (2015). Pure versus hybrid competitive strategies in the forest sector: Performance implications. Forest Policy and Economics, 54, 51-57. http://dx.doi.org/10.1016/j.forpol.2015.02.001

Hawes, J. M., \& Crittenden, W. F. (1984). A taxonomy of competitive retail strategies. Strategic Management Journal, 5(3), 275-287. http://dx.doi.org/10.1002/smj.4250050307

Helfat, C. E., \& Raubitschek, R. (2000). Product sequencing: Co-evolution of knowledge, capabilities and products. Strategic Management Journal, 21(10-11), 961-979. http://dx.doi.org/10.1002/1097-0266(200010/11)21:10/11<961::AID-SMJ132>3.0.CO;2-E

Hodgkinson, I. R. (2013). Are generic strategies 'fit for purpose' in a public service context? Public Policy and Administration, 28(1), 90-111. http://dx.doi.org/10.1177/0952076712440301

Huang, J. S. (2011). An examination of business strategies in the second life virtual market. Journal of Media Business Studies, 8(2), 1-17. http://dx.doi.org/10.1080/16522354.2011.11073520

Hurley, R. F., \& Hult, G. T. M. (1998). Innovation, market orientation, and organizational learning: An integration and empirical examination. The Journal of Marketing, 62(3), 42-54. http://dx.doi.org/10.2307/1251742

International Organization for Standardization- ISO. ISO/TS 16949:2009. Last reviewed in 2013. Retrieved from www.iso.org/iso/catalogue_detail?csnumber $=52844$

Invest in Turkey. The Republic of Turkey Prime Ministry Investment Support and Promotion Agency. Retrieved June 27, 2015 from http//www.inves.gov.tr

Kim, L., \& Lim, Y. (1988). Environment, generic strategies, and performance in a rapidly developing country: A taxonomic approach. Academy of Management Journal, 31(4), 802-827. http://dx.doi.org/10.2307/256339

Kim,Y., \& Choi, Y. (1994). Strategic types and performances of small firms in Korea. International Small Business Journal, 13(1), 13-25. http://dx.doi.org/10.1177/0266242694131001

Lähtinen, K., \& Toppinen, A. (2008). Financial performance in Finnish large-and medium-sized sawmills: The effects of value-added creation and cost-efficiency seeking. Journal of Forest Economics, 14(4), 289-305. http://dx.doi.org/10.1016/j.jfe.2008.02.001

Lapersonne, A., Sanghavi, N., \& De Mattos, C. (2015). Hybrid Strategy, ambidexterity and environment: toward an integrated typology. Universal Journal of Management, 3, 497-508. http://dx.doi.org/10.13189/ujm.2015.031204

Lechner, C., Gudmundsson, S. V., \& Vidar, S. (2014). Entrepreneurial orientation, firm strategy and small firm performance. International Small Business Journal, 32(1), 36-60. http://dx.doi.org/10.1177/0266242612455034

Leitner, K., \& Güldenberg, S. (2010). Generic strategies and firm performance in SMEs: A longitudinal study of Austrian SMEs. Small Business Economics, 35(2), 169-189. http://dx.doi.org/10.1007/s11187-009-9239-x

Lilien, G. L., Morrison, P., Searls, K., Sonnack, M., \& von Hippel, E. (2002). Performance assessment of the lead user idea generation process. Management Science, 48(8), 1042-1059. http://dx.doi.org/10.1287/mnsc.48.8.1042.171

Lippman, S. A., \& Rumelt, R. P. (1982). Uncertain imitability: An analysis of interfirm differences in efficiency under competition. The Bell Journal of Economics, 13(2), 418-438. http://dx.doi.org/10.2307/3003464

Mahoney, J. T. (1995). The management of resources and the resource of management. Journal of Business Research, 33, 91-101. http://dx.doi.org/10.1016/0148-2963(94)00060-R

Manev, I. M., Manolova, T. S., Harkins, J. A., \& Gyoshev, B. S. (2014). Are pure or hybrid strategies right for new ventures in transition economies? International Small Business Journal, 0266242614550322. http://dx.doi.org/10.1177/0266242614550322

McGee, J. E., \& Dowling, M. J. (1994). Using R\&D cooperative arrangements to leverage managerial experience: A study of technology-intensive new ventures. Journal of Business Venturing, 9(1), 33-48. http://dx.doi.org/10.1016/0883-9026(94)90025-6 
Miles, R. E., \& Snow, C. C. (1978). Organizational strategy, structure, and process. New York: McGraw-Hill.

Miller, D. (1988) Relating Porter's business strategies to environment and structure: Analysis and performance implications. Academy of Management Journal, 31(2), 280-308. http://dx.doi.org/10.2307/256549

Miller, D. (1991). Stale in the saddle: CEO tenure and the match between organization and environment. Management Science, 37(1), 34-52. http://dx.doi.org/10.1287/mnsc.37.1.34

Miller, J. (2003). The suggestion system is no system. Gemba Research LLC, November 2003, 3rd Ed., 1-11.

Mintzberg, H. (1988). Generic strategies: Toward a comprehensive framework. Advances in Strategic Management, 5 , $1-67$.

Mintzberg., H. (1990). The design school: Reconsidering the basic premises of strategic management. Strategic Management Journal, 11(3), 171-195. http://dx.doi.org/10.1002/smj.4250110302

Neagoe, L. N., \& Klein, V. M. (2009). Employee suggestion system (kaizen teian) the bottom-up approach for productivity improvement. International Conference on Economic Engineering and Manufacturing Systems, 10 (3), 361-366.

Noda, T., \& Collis, D. J. (2001). The evolution of intraindustry firm heterogeneity: Insights from a process study. Academy of Management Journal, 44(4), 897-925. http://dx.doi.org/10.2307/3069421

Olson, E. M., Slater, S. F., \& Hult, G. T. M. (2005). The performance implications of fit among business strategy, marketing organization structure, and strategic behavior. Journal of Marketing, 69(3), 49-65. http://dx.doi.org/10.1509/jmkg.69.3.49.66362

Parnell, J. A. (2013). Uncertainty, generic strategy, strategic clarity, and performance of retail SMEs in Peru, Argentina, and the United States. Journal of Small Business Management, 51(2), 215-234. http://dx.doi.org/10.1111/jsbm.12010

Parnell, J. A., \& Hershey, L. (2005). The strategy-performance relationship revisited: The blessing and curse of the combination strategy. International Journal of Commerce and Management, 15(1), 17-33. http://dx.doi.org/10.1108/10569210580000220

Pertusa-Ortega, E., Molina-Azorín, J., \& Claver-Cortés, E. (2007). Pure, hybrid or 'stuck-in-the-middle' strategies? A revision and analysis of their effects on firm performance. EURAM 2007: Annual Meeting of the European Academy of Management. Paris, 16-19 May 2007.

Pertusa-Ortega, E., Molina-Azorín, J., \& Claver-Cortés, E. (2009). Competitive strategies and firm Performance: A comparative analysis of pure, hybrid and 'stuck-in-the-middle' strategies in Spanish firms. British Journal of Management, 20(4), 508-523. http://dx.doi.org/10.1111/j.1467-8551.2008.00597.x

Pettus, M. L., Kor, Y. Y., \& Mahoney, J. T. (2009). A theory of change in turbulent environments: The sequencing of dynamic capabilities following industry deregulation. International Journal of Strategic Change Management, 1(3), 186-211. http://dx.doi.org/10.1504/IJSCM.2009.024509

Porter, M. (1980). Competitive strategy: Techniques for analyzing industries and competitors. New York: Free Press.

Porter, M. (1985). Competitive advantage. New York: Free Press.

Porter, M. (1996). What is Strategy? Harvard Business Review, 74(6), 61-78.

Proff, H. (2000). Hybrid strategies as a strategic challenge-The case of the German automotive industry. Omega, 28(5), 541-553. http://dx.doi.org/10.1016/S0305-0483(00)00018-9

Proff, H. (2007). Strategies for German automotive manufacturers facing new competitors from low cost countries. Retrieved November 20, 2015 from https://www.zu.de/info-wAssets/zu-schnitt/zuschnitt_012.pdf

Raynor, M. E. (2007). The strategy paradox: Why committing to success leads to failure (and what to do about it). Toronto: Doubleday.

Reitsperger, W. D., Daniel, S. J., Tallman, S. B., \& Chismar, W. G. (1993). Product quality and cost leadership: Compatible strategies? Management International Review, 33, 7-21. http://www.jstor.org/stable/40228175

Robinson, R. B., \& Pearce, J. A. (1988). Planned patterns of strategic behavior and their relationship to business-unit performance. Strategic Management Journal, 9, 43-60. http://dx.doi.org/10.1002/smj.4250090105

Roos, A., Flinkman, M., Jäppinen, A., Lönner, G., \& Warensjö, M. (2002). Identification of value-adding strategies in the Swedish sawn wood industry. Scandinavian Journal of Forest Research, 17(1), 90-96. http://dx.doi.org/10.1080/028275802317221127 
Rothaermel, F. T., \& Hess, A. M. (2007). Building dynamic capabilities: Innovation driven by individual-, firm-, and network-level effects. Organization Science, 18 (6), 898-921. doi:10.1287/orsc.1070.0291

Salavou, H. E. (2010). Strategy types of service firms: Evidence from Greece. Management Decision, 48(7), 1033-1047. http://dx.doi.org/10.1108/00251741011068752

Salavou, H. E. (2013). Hybrid strategies in Greece: A pleasant surprise. European Business Review, 25(3), 301-314. http://dx.doi.org/10.1108/09555341311314834

Salavou, H. E. (2015). Competitive strategies and their shift to the future. European Business Review, 27(1), 80-99. Http://dx.doi.org/10.1108/EBR-04-2013-0073

Samsunlu, A. (2007). The competitive strategies that Turkish automotive supplier industry is faced with both in domestic and international markets. Journal of Global Strategic Management, 2, 40-50.

Sanchez, R. (1995). Strategic flexibility in product competition. Strategic Management Journal, 16, 135-159. http://dx.doi.org/10.1002/smj.4250160921

Shank, J. K., \& Govindarajan, V. (1992). Strategic cost analysis of technological investments. MIT Sloan Management Review, 34(1), 39-52.

Shinkle, G. A., Kriauciunas, A. P., \& Hundley, G. (2013). Why pure strategies may be wrong for transition economy firms. Strategic Management Journal, 34(10), 1244-1254. http://dx.doi.org/10.1002/smj.2060

Spanos, Y. E., Zaralis, G., \& Lioukas, S. (2004). Strategy and industry effects on profitability: Evidence from Greece. Strategic Management Journal, 25(2), 139-165. http://dx.doi.org/10.1002/smj.369

Thompson, A. A., \& Strickland, A. J. (1999). Strategic management, concepts and cases. (11th ed.). Boston: McGraw-Hill Irwin.

Thornhill, S., \& White, R. E. (2007). Strategic purity: A multi - industry evaluation of pure vs. hybrid business strategies. Strategic Management Journal, 28(5), 553-561. http://dx.doi.org/10.1002/smj.606

Venkatraman, N. (1989). Strategic orientation of business enterprises: The construct, dimensionality and measurement. Management Science, 35(8), 942-962. http://dx.doi.org/10.1287/mnsc.35.8.942

Wasti, S. N., Kozan, M. K., \& Kuman, A. (2006). Buyer - supplier relationships in the Turkish automotive industry. International Journal of Operations \& Production Management, 26(9), 947-970. http://dx.doi.org/10.1108/01443570610682580

Womack, J., Jones, D., \& Roos, D. (2007). The machine that changed the world. New York: Simon \& Schuster.

Wright, P., Kroll, M., Tu, H., \& Helms, M. (1991). Generic strategies and business performance: An empirical study of the screw machine products industry. British Journal of Management, 2(1), 57-65. http://dx.doi.org/10.1111/j.1467-8551.1991.tb00016.x

Note 1: The letter "W" was assigned as a nickname for the automotive wire harness supplier company used in case study to be more understandable in following text.

\section{Copyrights}

Copyright for this article is retained by the author(s), with first publication rights granted to the journal.

This is an open-access article distributed under the terms and conditions of the Creative Commons Attribution license (http://creativecommons.org/licenses/by/3.0/). 